\title{
1. Migration and freedom
}

Freedom of movement: 'the first and most fundamental of man's liberties'. (Cranston 1973, What are Human Rights?, p. 31)

\section{INTRODUCTION}

There are an estimated 214 million international migrants and approximately 740 million internal migrants in the world today. ${ }^{1}$ In spite of these global migration flows, there is no guarantee of the right of freedom of movement, and most migration takes place against a backdrop of both official and unofficial controls. International migrants seeking to establish themselves even temporarily in a new setting must confront numerous state restrictions in the form of visas, fees and quotas, not to mention proof of resources, residency, employment, identification and other regulations. Even internal migrants find their mobility constrained by governmental requirements that may curb their opportunities to settle in new surroundings. In addition to state controls, migrants also face many administrative and social obstacles as 'newcomers', 'outsiders' or 'foreigners', and are frequently denied entry to protected spaces, above all in the housing and labour markets, further discouraging them from establishing new lives elsewhere.

This book considers some of the above challenges. The starting point is a re-examination of the right of freedom of movement. The concept of freedom of movement and its relationship to migration has received little comprehensive treatment among academics, yet it underpins much of what we expect as individuals living in liberal states. Hannah Arendt, who mistrusted states and saw them as sources of antagonism and the violation of human rights, also believed that the free movement of people was the bedrock for both human existence and democracy - without free movement we would be confined to slavery (Alonso-Rocafort 2009). Arendt's argument aligns with the views held by ancient Delphic priests (Moses 2006), for whom the right to come and go and be protected against detention was one of the four fundamental elements of freedom (Westermann 1955). More recently Satvinder Juss has advanced a 
sophisticated argument that draws upon historical and legal sources to suggest that without freedom of movement, other rights and universal values including 'mutual aid', 'hospitality' and 'good faith' are precarious, as is global stability (Juss 2004, pp. 289-90). The aim of this book is to explore such assertions by investigating the experiences of migrants and in so doing assess the pretentions of international and national provisions regarding rights to freedom of movement.

Legal foundations for the free movement of people include the American Declaration on the Rights and Duties of Man that first linked rights to nationality, residency and movement under Article VIII (International Conference of American States 1948). Some eight months later, the right to freedom of movement was explicitly elaborated in Article 13 of the 1948 Universal Declaration of Human Rights which states that: 'Everyone has the right to freedom of movement and residence within the borders of each State. Everyone has the right to leave any country, including his own, and return to his country' (UN General Assembly 1948). Subsequent bodies of international law, including UN conventions and regional conventions, have affirmed the right to free movement alongside other human rights protections, ${ }^{2}$ thereby giving greater weight to claims that freedom of movement should be seen as a gateway right.

We note one important caveat: the scope and application of the right to freedom of movement. International law establishes provisions for international migration under certain conditions (e.g. the right to seek asylum); the principle of freedom of movement, however, has generally been accepted to apply within a state's borders, where it remains the prerogative of sovereign states. Arguments for restricting freedom of movement between states include claims over the preservation of sovereignty, where non-citizens are considered a potential threat to the state's resources and ideological foundations. According to the sovereigntybased argument, immigration controls are justified to defend borders and to protect interests that may be upset by the entry of large numbers of foreign nationals. This is a crude version of the argument, and we note that in practice several categories of foreigner have been identified as beneficial to the state and have been admitted (e.g. migrant labourers, professionals and students). Nonetheless the relationship between freedom of movement, the rights of non-citizens and the host state remains highly contested. 


\section{INTERNATIONAL LAW AND THE TREATMENT OF FOREIGNERS IN HISTORY}

International law acknowledges that the rights of foreigners do not include full participation in the host state, but such participation has generally been understood to apply to political rights. Non-citizens enjoy all human rights irrespective of citizenship status just as do formal citizens, unless exceptional distinctions serve a legitimate state objective (Weissbrodt 2008). Nationality itself is not therefore a basis for discrimination. International law specifically records that nationality laws must be consistent with general principles of international law with respect to non-discrimination against non-citizens as affirmed in the 1923 decision by the Permanent Court of International Justice (1923) and Article 1 of the 1930 Hague Convention on Certain Questions Relating to the Conflict of Nationality Laws (League of Nations 1930). Yet the degree to which migrants may actually participate remains a grey area, and many non-citizens are excluded from a range of civic activities in the host state and struggle to see their human rights protected. Citizenship remains a common basis for differentiating between groups and for allocating state entitlements.

Furthermore, while citizenship may be acquired by means of naturalization in most states, thereby offering a route to greater participation, it is far from straightforward. Successful naturalization is conditional upon the applicant addressing specific criteria, often residency qualifications and language and citizenship tests. Naturalization is granted at the discretion of the state, and we note that most states still privilege ethnic and ancestral claims, which themselves are often a proxy for nationality preferences (Bauböck and Wallace Goodman 2010). Moreover, many naturalized citizens still do not enjoy the full range of rights afforded to those who acquired citizenship at birth.

Sovereignty-based arguments have been extensively amended, refashioned and challenged. Almost all states now permit some non-citizens to enter, even if only temporarily (Gibney 1988a), not to mention the large numbers of additional 'illegal' or irregular migrants that test the state's abilities to police its borders. The presence of these non-citizens has been cited as a reason for rejecting the idea that sovereignty is either an objective or a fixed concept that may reasonably be called upon as a basis for determining entry to the state. Further historical claims of cosmopolitanism and extensive flows of migrants across politically defined jurisdictions lend support to claims that sovereignty is neither a just nor accurate basis for exclusion. We note Amos Hershey's essay 
published in 1911 on the international relations of Antiquity in which he identified considerable inter-state and inter-tribal life, for example in his discussion of the Greek practice of Proxeny whereby a citizen selected by the city-state hosted foreign ambassadors at his own expense, in return for honorary titles. Hershey calls attention to the Proxenos Alcibiades who represented Sparta at Athens (Hershey 1911). Subsequent archaeological evidence has also affirmed the presence of migrants as traders, military personnel, servants and slaves in a profoundly cosmopolitan order.

Other historical studies of the Ancient world depict a complex picture of the mobility and associated rights of foreigners, which was at times open and receptive and yet preferential and ordered. Roland de Vaux's account of resident aliens (the gerim) in Ancient Israel illustrates such ambiguity. He notes that in Ancient Israel identity and belonging were not simply the result of tribal ancestry but were defined by an active territorial connection. The gerim thus included not only foreigners but landless Levites and lone Israelites, all members of the House of Israel (De Vaux 1997), who tended to be grouped with the poor, widows and orphans. While the gerim enjoyed fewer religious rights than the Israelites, they are recorded in biblical passages as having equal status in civil and criminal law. ${ }^{3}$ They also enjoyed certain economic and social rights in that they were permitted to collect fallen fruit and olives and to participate in the tithe in the third year and in the produce of the Jubilee (De Vaux 1997).

While evidence of migration in Antiquity substantiates claims of cosmopolitanism, it is important to qualify both the rights to migration and settlement in Antiquity. Hershey advises that many other groups in Antiquity tolerated foreigners and admitted them into their territory, calling attention to the liberality of Indian Brahmans and recording that the Egyptians exchanged letters, presents and embassies and even forged marriage alliances with Kings of Mitanni, Assyria and Babylonia. Yet there were social divisions between such groups. Juss recalls that the presence of non-citizens in the Ancient Greek polis was even more complex in that the Hellenic world introduced multiple categories of status, distinguishing 'citizens' from 'barbarians' and later subdividing these into citizens, naturalized aliens, public guests, domicile aliens, non-domicile aliens and strangers (Juss 2004). While non-citizens could enter and enjoy the right of asylum, aliens were required to have patrons. Romans embraced naturalization within the Empire where foreigners were protected under the 'Jus Gentium'. Outside the Empire such rights did not apply. Nonetheless Hershey informs us that such toleration and openness had a lasting influence on subsequent European traditions, 
fashioning medieval universalism that he claims permitted considerable freedom of movement for specified classes of travellers (Hershey 1911). Yet it is important to stress that counter-claims could equally be found in Antiquity. Hershey records that Carthaginian merchants placed cruel restrictions on trade with foreigners and closed off the sea to some categories of foreigners. Arguably we can find evidence of both cosmopolitanism and mercantilism in Antiquity.

In the Medieval period, the place of foreigners and the rights to migration featured in royal policy but again with several inconsistencies. Many enjoyed no freedom of movement; serfdom was commonplace, armies were composed of indentured soldiers and Jews were expelled from England, France, and eventually Spain and Portugal. During Spain's Golden Age Spaniards were discouraged from leaving the country as economic skills were hoarded and mercantilism was embraced as central to the imperial state (Sznajder and Roniger 2009). Yet foreign merchants were permitted entry to these European kingdoms. Historical texts again provided further insights into the place of foreigners, suggesting some toleration of the right to migration, while the right to free movement was curtailed. The Magna Carta of 1215 (Runnymede Charter), and later the 1225 and 1297 versions of the Magna Carta, guaranteed the safety and right of entry and exit of foreign merchants; at the same time foreignborn knights, who were seen as a threat to the kingdom, were banished. The Magna Carta also records the place of bonded labour in its discussion of 'villeins' (peasant tenant farmers) who enjoyed no freedom of movement and feature in the document only in so far as they should be protected from crippling heavy fines that deprived them of their livelihood. ${ }^{4}$ The right to migration was therefore not understood to apply as a natural right but rather was defined by association with economic activity, which was sharply delineated. Thus while foreign merchants generally enjoyed considerable rights of passage, other categories of persons were tied to the land or saw their mobility determined by their service in the military or to royal or aristocratic households.

The emergence of the nation-state in the 17th and 18th centuries provides the context for much discussion over the idea of sovereignty and its relevance to subsequent discussions over border management and freedom of movement. In his account of the development of the passport, John Torpey argues that immigration control was not intrinsic to the idea of the state but rather was the introduction of surveillance mechanisms, above all the passport, which was used to legitimate the state's authority (1998). Until that point, there was considerable evidence of freedom of movement that, even if it was not always defined as a formal political right, was treated as a natural right (Dowty 1989; Moses 2006; Whelan 
1988), at least in Western Europe where the practice of serfdom had been banned. Juss developed this line of argument, making the bold assertion that there was an 'unbroken line of international morality that favoured the right to free movement' and that was not damaged by the emergence of the nation-state but continued during its ascendancy (Juss 2013, p. 11). Such claims may be informed by a closer analysis of the intellectual development idea of sovereignty and the state.

\section{SOVEREIGNTY, THE STATE AND MIGRATION}

The notion of sovereignty is attributed to Jean Bodin, though many claim Machiavelli introduced the term in his discussion of the state and the concept of 'lo stato' in The Prince, where he provides that public power may be separate from both ruler and ruled. In his Six Books of a Commonwealth (1576), Bodin set out a less contested definition derived from his claim that an orderly Commonwealth depended on the creation of a central authority that possessed unlimited power. Bodin's definition was later to be described as ruler sovereignty and had no bearing on the relationship between migrants and the emerging state, except in as far as such rights were derived by the ruler (Bodin 1992).

Since Bodin the idea of sovereignty has been expressed as the ultimate source of state power, de jure authority, limited governance, de facto power and influence. Common to all these notions is the separation of sovereignty into internal and external sovereignty, which raises important questions over the delineation of mobility rights. Internal sovereignty has traditionally designated the separation between ruler and ruled, providing one basis for determining membership. External sovereignty emphasizes territorial boundaries and political control over a defined area.

In his now classic work entitled Sovereignty, Hinsley (1986) argued that sovereignty is a theory or assumption of power, a theme repeated in much of the literature of the state (Ionescu 1974; Vincent 1987). Hinsley's definition supports the idea of 'state sovereignty', for which he finds considerable precedent. He traces the modern notion back to the period of Justinian rule when the idea of power and authority entered the vernacular. Vincent (1987) similarly argues that the vocabulary for sovereignty came into effect at this point through the introduction of the terms 'potestas' and 'auctoritas', which denoted official power and influence or prestige, respectively. The division between rule by a single central authority and the role of the public was further defined in the concept of 'lex regia' in the Justinian compilation of Roman Law, 'Corpus iuris', which provided the basis for rule by law, where people 
transferred their powers to the emperor. It is precisely this division and transference of authority that some claim makes the idea of sovereignty relevant. For David Held, such notions of sovereignty should be seen more as a form of legal authority or entitlement (1989).

The above definitions have been contested by post-modern theorists and others who argue that sovereignty marks a site of political struggle and not a fixed concept (Weber 1995). The term is no longer coextensive with the idea of the unitary state, nor does it relate to political ideas developed in the 16th and 17th centuries; furthermore, such arguments are at odds with empirical observations regarding the inter-state movement of people, which challenges statist ideas of political power (Deutsch 1978; Rosenau 1974; Weber 1995). Karl Deutsch, for example, argues that in order for sovereignty to be meaningful, it must be equated with the centralization of power, the monopolization of information and the concentration of decision-making authority.

An even more essential characteristic of sovereignty is the absence of any recognized input channel of controlling or overriding information from outside the system. In the theory of sovereignty no outside organizations, as well as no preferences or values, may be permitted to interfere with the working out of the internal decision probabilities of the system. (Deutsch 1969, p. 108)

Thus for Deutsch the development of international and interdependent relations dealt a blow to the idea of state sovereignty.

Others have suggested, however, that the idea of de jure sovereignty is more relevant. Rather than stress the idea of state unity, they advocate reconceiving sovereignty as limited power, following Locke's conclusion in the Two Treatises of Government (1993) that sovereignty, although executed by the sovereign and the state, resides with the body politic (Middleton 1969; Schwarzenberger 1969; Stankiewicz 1969). Both Kavanagh and Spiro (1974), for example, dismiss Deutsch's transactional argument against sovereignty, maintaining that trends in interdependence have not destroyed constitutional independence. Held (1989) similarly suggests the term can be recast, provided one acknowledges five key gaps that complicate the usage of the term 'sovereignty', not least because they include reference to inter-state migration. These are: (i) shifts in the world economy; (ii) the development of regional trading blocs that influence the actions of states; (iii) the expansion of international organizations and regimes; (iv) the development of international law; and (v) the end of domestic policy as a result of transnational movements. In spite of these gaps, he notes that states retain ultimate sovereignty in that they alone reserve the right to go to war. 
Contrary to the claims made by both Torpey and Juss about the permissiveness of liberal thought, several counter-precedents can also be found in the development of moral and political philosophy. We note, for example, the relevance of Rousseau's work for communitarian theory, much of which is opposed to the free movement of people and relaxation of immigration controls. While Rousseau believed sovereignty was retained by the people, he reached a different conclusion from Locke and explicitly discounts any possible division between political rule and society. In 'The Social Contract' he writes, 'Sovereignty cannot be represented for the same reason that it cannot be alienated; its essence is the general will and cannot be represented - either it is the general will or it is something else; there is no intermediate possibility' (Rousseau 1987, p. 141). The conclusions that follow from Rousseau's account are logically opposed to the idea of an individualized right of freedom of movement as set out in national constitutions and more recently in international law.

During the past 20 years political scientists have included population concerns alongside their studies of territory and authority in their treatment of sovereignty; the rights of migrants are not, however, well defined in this body of writing (Biersteker and Weber 1996). Scholars may interpret the origin of freedom of movement as a concept, but its intellectual connection to the idea of the state and its relevance to the multiple definitions of sovereignty most clearly enter the picture in historical accounts of late 19th and early 20th century discussions over nationality and citizenship. Notions of mobility rights developed independently for the most part from writings on the state, sovereignty and political authority.

\section{INTERNAL MIGRATION AND ASSOCIATED FRONTIERS OF INEQUALITY}

If, as Torpey argues, immigration controls and the institutionalization of the passport served primarily to legitimate the state's authority over migration policy, we note that the right to internal migration has also been subject to state interference. Although the relationship between the driving forces for such intrusion is notably different from the context Torpey describes, the impediments experienced by internal migrants nonetheless also raise questions about the pretentions of citizenship and the normative assumptions of international law. A central premise of this book is therefore that the idea of free movement within states is also contested by the number of state-sanctioned controls that apply in 
varying degrees to immigrants and domestic migrants, formal citizens and non-citizens and many categories in between.

In practice, the distinction between the mobility rights of those within the state and those seeking to move between states is also in dispute. Consider, for example, the case of skilled migrants. Recent data from the OECD record that the most qualified among them have a wide choice of destination countries and are found across the globe, as illustrated in Table 1.1. The table presents the image of a globalized pool of talent. Following the completion of the European Single Market in 1992 and the Uruguay Round in 1994, a global trading regime, the product of which is represented in Table 1.1, was created. What is not visible is the complexity of flows of highly skilled migrants, including short- and long-term migrations, return flows and multiple relocations between advanced states and developing regions, though these are recorded elsewhere.

Yet these global flows of highly skilled migrants are not unrestricted but rather are still shaped by political forces, as illustrated in the use of preferential immigration policies to restock labour and in international recruitment drives that are aimed to attract specific categories of migrant (see Lavenex 2006). Moreover, such flows are not unlimited. There are caps on the numbers of highly skilled that may be admitted into any host state. Several countries have followed the US lead of setting quotas for skilled migrants (e.g. Australia and Germany), while many other advanced states rely instead on a points-based system which rewards applicants for certain qualifications, such as level of education, language competency, knowledge of the prospective country of settlement and local family ties to the host state. Countries that have adopted this model include New Zealand (1987), which adopted a mixed approach of quotas and points; Australia (1988); Hong Kong (2006); France (2007); and the United Kingdom (2008). Other countries have introduced de facto points systems, basing entry qualification upon similar criteria but without actually counting up 'points'. Under such immigration schemes, skilled migrants must demonstrate proof of language proficiency, residency requirements and health checks, and might also be subject to age restrictions.

Skilled migrants, once admitted, face additional challenges that are not immediately obvious. For example, highly skilled migrants do not necessarily have the freedom to leave their employment while retaining their immigration status in the host state; rather (as is practised in the United Kingdom) their jobs may be 'pegged' to their place of sponsored employment. Consequently immigrants do not necessarily enjoy as much flexibility in the labour market, as internal relocation is complicated by administrative requirements, including the need of further sponsorship 


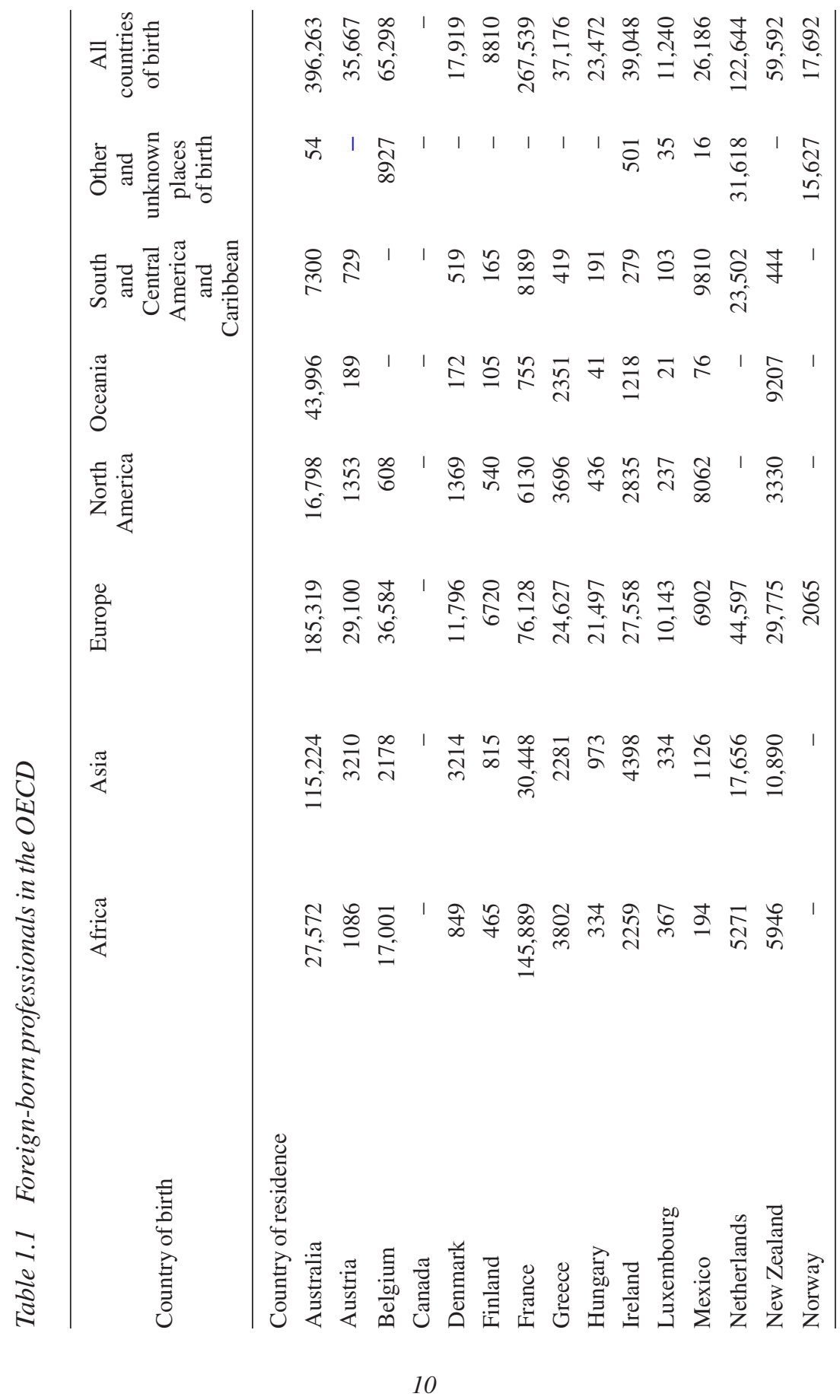




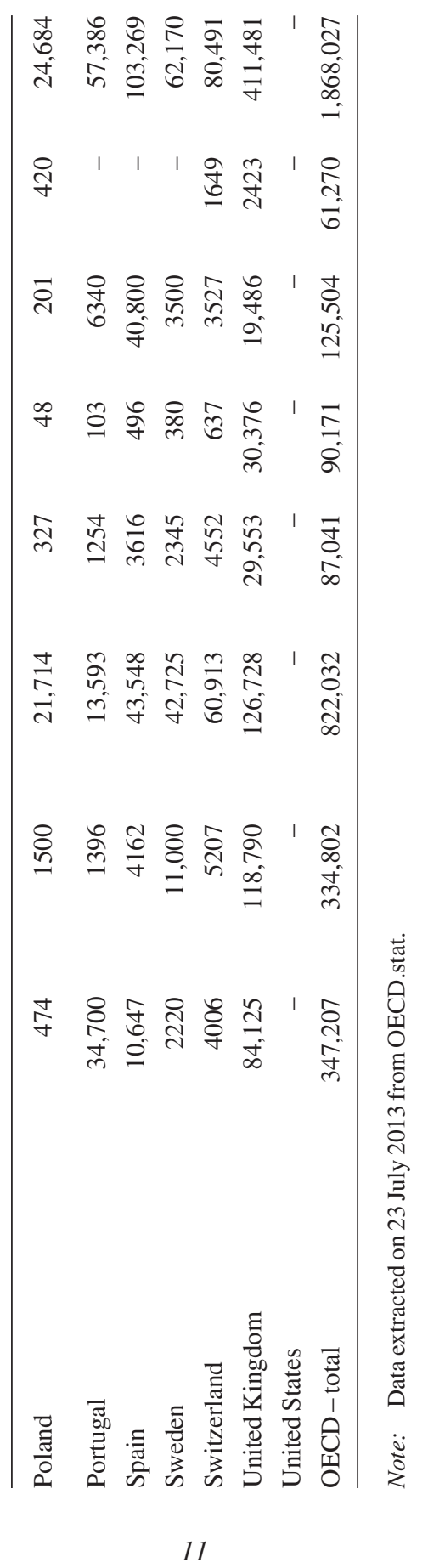


and a second application for permission to work. Even highly skilled migrants who move within a state where they have the right to remain face the burden of providing documentation before they can establish their residence elsewhere, send their children to school or visit a doctor.

Displaced people, who in contrast to highly skilled migrants are among the least privileged, face multiple restrictions on both sides of the state border. Refugees and others in need of humanitarian protection are challenged at every stage of their migratory journey, even after successfully navigating some considerable barriers. Before they reach the extremities of the Mediterranean or Andaman Sea, prospective asylum seekers must secure passage from their home state, which may entail paying smugglers or purchasing visas, documents and costly airline tickets and then skirting the watchful eye of immigration and asylum liaison officers instructed to deter their departure. The perils of seeking refuge in another state include the prospect of encampment in inhospitable, crowded and often dangerous conditions; detention in the host state while applications for asylum are processed; then additional delays, uncertain procedures and potential legal challenges. During this time asylum seekers are normally denied the right to work even as they face other obstacles that undermine the chances of their successful integration into the host state.

Internally displaced people may face an even more precarious flight with fewer options of protection at the end. Often the only difference between the situation of the internally displaced person and the recognized refugee is that the latter has managed to cross an international border. Both may have experienced persecution as defined in the 1951 Refugee Convention, yet one remains in the state where the persecution was initiated. While asylum seekers may be held in a camp or centre, having surrended their autonomy to the UNHCR, Red Cross or a host government, internally displaced persons may similarly find their mobility limited by their encampment, imposed curfews, formal and selfsegregation, a lack of adequate housing and opportunities for employment - not to mention considerable threats to their personal security from armed groups associated with state or non-state actors. It is an incontrovertible fact that asylum seekers, refugees and internally displaced people lead unfree lives.

Other groups of international migrants, such as students and, to a lesser extent, retirees who have settled abroad, face a range of political and bureaucratic obstacles that also undermine their rights to mobility and settlement. Students seeking to study abroad may, for example, be subject to internal controls by their home state that may seek to discourage their exit for fear of 'brain drain'; this may take the form of fees or other 
requirements that must be satisfied before a student is entitled to leave. Host states may also place further restrictions on their entry, fearing that future graduates will remain in the country and may effectively displace nationals and force those with more favoured status out of the labour market. Like other categories of international migrant, they too face the burdens of fees, visas, financial guarantees and other limitations that set them apart from home students. State protectionism is an all too common response to the global politics of brain drain and brain gain alike.

Even within states the rights and entitlements of students vary considerably. In spite of attempts to promote internal markets in the European Union, for example, students in these regions experience different fee regimes based on their local place of residence. This applies even before one considers the possibility of intra-state mobility and out-of-state tuition. University students from Scotland who study at a Scottish university are currently exempt from tuition fees, unlike English students who wish to pursue their studies at another university in England. While students from neighbouring states may have the right to study in Scotland, the different fee regimes for home students versus non-home students illustrate further disparities that result from the exercise of mobility rights. Similar arguments may be made regarding access to reproductive rights in the USA or the European Union, where provisions vary from one state to another. Far from being unified, the market has become diversified, and people's entitlements are increasingly differentiated on the basis of local residency, among other criteria.

This book explores the relationship between mobility and citizenship. It re-examines the foundational claims of freedom of movement as a gateway right confined to intra-state mobility. In this context, freedom of movement is taken to apply to rights of entry and exit as well as the right to remain in one's own state. A central premise of this book is that the study of mobility illuminates the ways in which citizenship is understood and institutionalized within the state. By investigating the experiences of individual migrants, this book contends that we may gain a better understanding of the relationship between the political rights (in this context mobility rights) and social, economic and cultural rights that are at the core of personal liberty.

We note that successful migration is dependent on structural constraints, social barriers and individual factors, including ethno-national affiliations; age, sex, gender; educational level and linguistic ability; job status and occupational profile; social and professional networks; and residency. These constraints, in turn, serve to define a range of migrants whose personal identities, social and official status are often shaped by their degrees of access. Hence one may speak of various types of skilled 
or unskilled migrant, asylum seekers, refugees, displaced persons, students, tourists and expats who may identify as 'EU nationals', 'retirees', 'greencard holders', 'illegal' and 'irregular migrants' and 'trafficked persons', and so on.

The following observations are noted.

First, the ideas of freedom of movement and open borders are not identical. While free movement assumes open borders, the two are conceptually distinct. Opening up borders does not necessarily remove inequality or permit mobility. Furthermore, we note that the logic behind the open borders, communitarian and liberal nationalist arguments is overly dependent on push-pull models of migration, which fail to convey the context in which much migration takes place today. Immigration may be a livelihoods strategy but the idea that people move because of wage differentials between states or purely to improve their lot fails to acknowledge the complex interplay of autonomy, family and social networks, culture and other personal factors in the migration decisionmaking experience.

Secondly, there is an overriding statist bias in much discussion of migration that fails to recognize inequality within states. Although communitarians acknowledge diversity within states, their approach essentializes sub-national polities and ignores contestation between interest groups. There is an equal presumption that immigration policies are consistent, rational and effective, yet this is often far from true, as discussed below. The main exceptions to this are the transnationalists and critical economists and sociologists (e.g. the World Systems theorists) who believe that the world-system, namely the inter-regional and transnational division of labour, should be the primary unit of social analysis rather than the state. In order to capture such contestation, a more nuanced model is required.

Thirdly, and related to the above, the idea of borders is always assumed rather than questioned. Much of literature fails to recognize that, in some cases, borders are actively delegitimized or ignored. Here we may think of the many activists who assist those fleeing from Mexico to cross the border into the USA. Such subversion in itself raises a normative challenge to the exclusion of certain groups but even in the case of regular migration the erection of borders is not in itself evidence that borders prevent mobility. As Wendy Brown argues, even the walls dividing Texas from Mexico or South Africa from Zimbabwe may be little more than theatrical props which are frequently breached and blur the distinction between law and lawlessness they are intended to represent (Brown 2010). Borders demarcate jurisdiction of authority not necessarily mobility rights (Bauböck 2009, p. 10). 
This book responds to the above-mentioned limitations by examining five central themes: (1) freedom of movement as a condition for action; (2) motivations for migration; (3) the relationship between open borders and freedom of movement; (4) the relationship between freedom of movement and democracy; and (5) the role of the state in promoting free movement. Rather than consider the well-charted issue of international migration, it explores the barriers to freedom of movement experienced by migrants inside the state. Borrowing Fitzgerald's (2006) recommendation for a neo-pluralist approach to understand inter-state migration, this study seeks to explore how competing interests within the state influence the ways in which - and the degrees to which - migrants access and enjoy their rights to mobility. The following chapters examine both conditions migrants face once they have moved and also the challenges introduced by the process of moving, including the problems of securing rights to residency, settlement, and associated social and economic privileges.

The setting for this study is contemporary Europe. There are several reasons for this choice of focus. First, of all the regions of the world, Europe has committed itself to the principle of the free movement of people. The right to free movement is enshrined in the EU's Treaties and has been affirmed in secondary legislation and in case law. A parallel body of European human rights law developed through the Council of Europe system also provides for the right to freedom of movement as set out in the European Convention on Human Rights (Protocol 4). Secondly, the aforementioned issues are of great political interest in contemporary Europe, where the status of migrants is the source of considerable debate regarding the identity of the liberal state and the degree to which it may admit or exclude non-citizens on the basis of immigration, asylum or security concerns. Thirdly, the European continent provides a diverse setting for analysis: it is the site of supranational development, regionalization and devolution; it enjoys a common system of external border controls, visa restrictions and anti-terror policies on detention and removal; and it remains a place of transition and a recent destination for the former states of Eastern Europe, the former Soviet Union and Yugoslavia.

This book begins with a review of the discourses on freedom of movement and the relevant institutional, legal and political context. The following chapter discusses the development of freedom of movement in European Union law and the European human rights law as developed by the European Court of Human Rights. This chapter sets the scene for the subsequent case studies which examine specific examples wherein migrants have tried to assert their rights to free movement.

The empirical basis for this study is the product of countless hours of field research with individuals in Croatia, Italy, Slovenia, Spain and the 
United Kingdom. In addition this book includes a specific chapter on Russia, which serves as a contrast, as a state outside the European Union and one where there have been exceptionally stringent barriers to an individual's free movement within the state, not to mention restrictions on the right to emigration. The methodologies used include semistructured interviews with migrants and their families, focus groups and further consultations with legal experts and human rights monitors. While qualitative research of this kind cannot claim to be representative, it is nonetheless informative and offers a window into the conditions facing people who may be overlooked in contemporary accounts of migration.

The first two case studies examine the experiences of professional migrants who have asserted their rights to freedom of movement within the European Union by relocating to another European Union member state. Chapter 4 describes the experiences of Spanish doctors who were recruited to work in County Durham in the North East of England. It draws upon interviews with the Spanish doctors and recruiters from the UK government to describe a set of initially positive outcomes where a select group of migrants have been able to establish themselves in the United Kingdom. It describes how their exercise of the right to free movement was facilitated by means of an Anglo-Spanish agreement between the Ministries of Health, which enabled professionals to assist their relocation. While noting the benefits of their move, this chapter also records how some doctors have become 'locked out' of their home country and 'locked into' the British system. It concludes with the doctors' assessment that societal and organizational barriers within the Spanish medical establishment may hinder the prospect of their return, thus limiting their mobility options in the future.

Chapter 5 presents a contrasting account of the challenge of freedom of movement within the European Union. It examines the difficulties language teachers from other EU member states have faced as they sought to work and settle in Italy. It describes how the pressure to open up the university system to foreigners resulted in a backlash against non-Italian language teachers, known as 'lettori', who had been working in the university system since 1989. Their plight formed the basis for four judgments by the Court of Justice of the European Union against the Italian universities, which it ruled had been guilty of nationality-based discrimination.

Chapter 6 examines the mobility options of returning refugees in Croatia, the newest EU member state, and describes the different fates of ethnic Serbs and Croats and their divergent reintegration experiences in post-war Croatia over the past 20 years.

Chapter 7 provides a contrasting example of a state where sub-national actors have frustrated the creation of a liberalized internal migration 
market. It describes the introduction of a 'registration' policy in Russia that requires migrants to inform the authorities when they move between cities. This policy carries over many aspects of the former Soviet 'propiska' system which controlled entry to Russian cities and determined access to a host of other social rights and scarce resources, including food and housing. Chapter 8 presents possibly the most disturbing account of where the right to freedom of movement, alongside a host of other fundamental rights in Slovenia, was revoked.

The final chapter revisits the normative claims of both European Union law and international law regarding the right to free movement as a foundational right. It reiterates the ways in which freedom of movement affects the enjoyment of social, economic and cultural rights and suggests that freedom of movement should therefore be considered in relation to the idea of personal freedom and hence citizenship.

\section{NOTES}

1. For a reliable account of current estimates, see United Nations Population Division (2009) and Bell and Muhidin (2009).

2. See also International Covenant on Civil and Political Rights (Article 12); International Convention on the Elimination of All Forms of Racial Discrimination (Article 5(d)(i)); Convention relating to the Status of Refugees (Article 26); Fourth Protocol to the European Convention for the Protection of Human Rights and Fundamental Freedoms (Articles 2 and 3); African Charter on Human and Peoples' Rights (Article 12); American Convention on Human Rights (Article 22).

3. De Vaux provides the biblical sources for his claims, noting that the gerim observed the Sabbath (Exodus 20:10, Deuteronomy 5:14) and the Day of Atonement (Leviticus 16:29); they offered sacrifices (Leviticus 17:8, for example) and participated in religious festivals (Deuteronomy 16:11, 16:14); and they observed the laws of purity (Leviticus 17:8-13). If circumcised, they could partake of the Passover sacrifice (Exodus 12:48-9).

4. See Treasures in Full: Magna Carta, http://www.bl.uk/treasures/magnacarta/translation/ mc_trans.html (last accessed 13 January 2014). 